\title{
Cercospora leaf spot of sugar beet (Cercospora beticola Sacc.) Part II. Prevention of occurrence, protection against cercospora leaf spot, resistance to fungicides
}

\author{
Chwościk buraka cukrowego (Cercospora beticola Sacc.) \\ Część II. Zapobieganie występowaniu, ochrona przed chwościkiem, \\ odporność na fungicydy
}

\author{
Agnieszka Kiniec ${ }^{1 *}$, Jacek Piszczek ${ }^{1}$, Adam Sitarski ${ }^{2}$
}

\section{Summary}

Cercospora beticola Sacc. is the most destructive foliar pathogen of sugar beet (Beta vulgaris L.) in many beet growing regions of the world. This paper summarizes the most important knowledge about the prevention of fungal infections, as well as the mechanisms of sugar beet resistance to infection. The methods of chemical protection of sugar beet against $C$. beticola and the action of active substances on the physiological processes of the fungus have been described as well. The factors stimulating resistance of $C$. beticola to fungicides and methods of preventing this phenomenon were indicated. The presented discussion was based on Polish and worldwide literature.

Key words: Cercospora beticola, sugar beet resistance, fungicide protection, fungus resistance, resistance mechanisms

\section{Streszczenie}

Cercospora beticola Sacc. jest najgroźniejszym patogenem liści buraka cukrowego we wszystkich rejonach uprawy tej rośliny. W niniejszym opracowaniu zebrano najważniejszą wiedzę dotyczącą zapobiegania zakażaniu roślin przez grzyba, a także mechanizmów odporności buraka cukrowego na infekcję. Omówiono metody ochrony chemicznej buraka przed chorobą oraz działania substancji czynnych na procesy fizjologiczne grzyba. Wskazano na czynniki stymulujące odporność $C$. beticola na fungicydy i metody zapobiegania temu zjawisku. Całość zagadnienia omówiono w oparciu o polską i światową szeroką bazę literaturową.

Słowa kluczowe: Cercospora beticola, odporność buraka, ochrona chemiczna, odporność grzyba na fungicydy, mechanizmy odporności

\footnotetext{
${ }^{1}$ Instytut Ochrony Roślin - Państwowy Instytut Badawczy

Terenowa Stacja Doświadczalna w Toruniu

Pigwowa 16, 87-100 Toruń

${ }^{2}$ Kutnowska Hodowla Buraka Cukrowego Sp. z o.o.

Straszków 12, 62-650 Kłodawa

*corresponding author: a.kiniec@iorpib.poznan.pl
} 


\section{Zapobieganie występowaniu i ochrona buraka przed Cercospora beticola - agrotechnika I Prevention and protection of beets before Cercospora beticola - agrotechnics}

Poszukiwania nowych metod zapobiegania i ograniczania szkodliwości chwościka buraka są prowadzone od dawna. Część z nich oparta jest o działania agrotechniczne, takie jak głęboka orka, odpowiednia rotacja upraw i eliminacja żywicieli wtórnych (Windels i wsp. 1998). Znaczącą rolę odgrywa prawidłowa rotacja upraw. Vereijssen i wsp. (2005) dowodzą, iż uprawa buraków na polu, na którym w glebie znajdują się porażone resztki liści, może przyspieszyć zakażenie nawet o cztery tygodnie. Również uprawa buraków na polach przylegających do pól, na których buraki były uprawiane w poprzednim sezonie, jest przyczyną szybszego wystąpienia zakażenia. Rotacja przy uprawie buraka cukrowego powinna wynosić minimum cztery lata. Wczesne i silne występowanie chwościka przy skracaniu płodozmianu potwierdzono także w badaniach prowadzonych w Polsce (Górski i Piszczek 2008; Piszczek 2010).

\section{Odporność buraka na Cercospora beticola I Resistance to Cercospora beticola in sugar beet}

Metodą skutecznego ograniczania szkodliwości chwościka jest hodowla odpornościowa. Odmiany odporne znajdujące się w użytkowaniu różnią się między sobą stopniem odporności (Pfleiderer i Schäufele 2000). Różnice te powodowane są wielogenową naturą odporności buraka na Cercospora beticola (Rossi i wsp. 2000). Odmiany odporne charakteryzują się dłuższym czasem kiełkowania na nich zarodników grzyba, co przekłada się na opóźnienie infekcji (Rossi i wsp. 1999). Różnica ta może być znaczna i wynosić od kilku do kilkunastu dni (Gaurilcikiene i wsp. 2006). W warunkach silnej presji patogena odmiany odporne niechronione chemicznie mogą plonować gorzej od odmian nieodpornych, skutecznie chronionych przed $C$. beticola (Smith i Campbell 1996; Gaurilcikiene i wsp. 2006). W praktyce wskazane jest w uprawie stosowanie odmian o średniej odporności, które skutecznie chronione chemicznie dają wysoki i stabilny plon (Windels i wsp. 1998). Odporność na $C$. beticola warunkowana jest czteroma lub pięcioma genami (Smith i Gaskill 1970; Schäfer-Pregl i wsp. 1999). Źródłem tych genów jest dzika forma buraka Beta maritima (Beta vulgaris ssp. maritima). Po raz pierwszy zostały w ten sposób pozyskane i wprowadzone geny odporności na chwościka do form uprawnych buraka przez Muneratiego na początku XX wieku i dały one początek pierwszym europejskim, w tym polskim i niemieckim odmianom, oraz użyto ich także w pracach nad odmianami amerykańskimi i japońskimi. Koch i Jung (2000) wykryli cztery główne loci
QTL odporności na C. beticola. Jak podaje Draycott (2006), na podstawie szerszych badań, można się spodziewać obecności trzech, siedmiu lub czterech loci QTL odpowiedzialnych za odporność na chwościka. Warto zauważyć, że geny odporności na Cercospora mają tendencję do działania addytywnego, a wykorzystanie znajomości QTL może pozwalać na odpowiednie użycie wszystkich tych genów. W chwili obecnej geny te są wprawdzie wprowadzone do obu linii rodzicielskich, ale z uwagi na małe zróżnicowanie puli genowej manipulowanie nimi jest trudne. Dlatego rozszerzenie puli genowej jest bardzo pożądane, choć ostateczna ilość genów biorących udział w procesie odporności jest nieznana (Weiland i Koch 2004). Geny odporności na C. beticola znajduje się również w innych gatunkach rodzaju Beta (Luterbacher i wsp. 2004). Donosi o tym także Mesbah i wsp. (1997) oraz Panella i Lewellen (2007). Formy dzikie rodzaju Beta, jako źródła odporności były i są kolekcjonowane w rejonach ich naturalnego występowania, głównie podczas wypraw w rejony basenu Morza Śródziemnego, a bardziej współcześnie na terenie Azerbejdżanu, Iranu i Grecji. Rezultaty tych wypraw są przechowywane w bankach genów, głównie w USDA-ARS (United States Department of Agriculture-Agriculture Research Service) National Plant Germplasm System (NPGS), a także w International Data Base for Beta (IDBB), oryginalnie założonym w 1987 roku jako Center for Genetic Resources, w Wageningen w Holandii stanowiąc kolekcję holendersko-niemiecką. Obecnie IDBB jest prowadzone przez Julius Kühn-Institute w Quedlinburg w Niemczech. Obecnie ich kolekcja rodzaju Beta jest drugą co do wielkości w świecie pośród tego typu kolekcji, z 2320 akcesami złożonymi do kolekcji Beta w Institute of Plant Genetics and Crop Plant Research (IPK) w Gatersleben w Niemczech (Draycott 2006; Kole 2011).

Rośliny odporne na $C$. beticola są porażane, jednak objawy choroby są na nich słabsze niż na roślinach podatnych, a plamki mają mniejsze rozmiary. Jednocześnie na ich powierzchni produkowana jest mniejsza liczba zarodników (Rossi i Battilani 1990; Rossi 1995, 2000). Z uwagi na wielogenową odporność buraka cukrowego na $C$. beticola, rośliny odporne w warunkach silnej presji patogena wykazują różny stopień porażenia (Smith i Ruppel 1974). Mechanizm odporności roślin składa się z kilku czynników. Jednym z nich jest odporność na powierzchni liścia, powodująca że grzyb nie infekuje liści buraka (Pool i McKay 1916; Kovacs 1955; Schlösser 1969; Solel i Minz 1971; Whitney i Mann 1981; Burenin i Pilipenko 1987). Chodzi tu głównie o łatwość kolonizacji mezofilu przez grzyba, a także gęstość mezofilu. Różne opinie panują na temat możliwości kiełkowania zarodników na powierzchni liścia. Solel i Minz (1971) oraz Feindt i wsp. (1981) twierdzą, że kiełkowanie zarodników na liściach roślin podatnych i odpornych jest takie samo przy tym samym wieku liścia. Z kolei badania dokonane przez Brillova i wsp. (1973) dowodzą, że kiełkowanie zarodników na powierzchni liścia warunkowane jest 
zawartością substancji mineralnych w liściu. Odporność wewnątrz liścia może prowadzić do spowolnienia rozwoju grzyba (Whitney i Mann 1981). Infekcja może prowadzić także do wzrostu zawartości składników fenolowych oraz zwiększać aktywność polifenolooksydaz i peroksydaz (Brillova i Sladka 1976), oraz zmian w strukturze pektyn (Steinkamp i wsp. 1979), suberyn i lignin (Srobarova i Brillova 1982). Solel i Minz (1971) sugerują, że interakcja mechanizmów odporności zależna jest od konkretnego patotypu C. beticola.

Najwyższą skutecznością w walce $\mathrm{z}$ chwościkiem charakteryzują się fungicydy. Są one podstawowym narzędziem ochrony buraków cukrowych, jednakże ich użycie musi być rozpatrywane jako część integrowanej ochrony roślin (Meriggi i wsp. 2000; Piszczek i Mrówczyński 2012). Czas i liczba stosowanych zabiegów ochronnych oraz użyte fungicydy nie mogą być określone z góry. Zależne jest to od momentu wystąpienia choroby, obecności w środowisku szczepów grzyba odpornych na fungicydy, obecności innych chorób liści, typu użytych odmian, wpływu zabiegów agrotechnicznych, warunków pogodowych oraz długości okresu czasu pozostałego do końca sezonu wegetacyjnego (Meriggi i wsp. 2003). Ochrona chemiczna opiera się na fungicydach kontaktowych oraz systemicznych. Aktualna lista dopuszczonych do stosowania fungicydów znajduje się na stronach internetowych Ministerstwa Rolnictwa i Rozwoju Wsi (Anonim 2018). Należy zaznaczyć, że fungicydy kontaktowe wykazują największą skuteczność podczas zabiegów w początkowych fazach infekcji (Borecki 1984) i powinny być stosowane do zabiegów zapobiegawczych. Jednak nie jest to zgodne z założeniami integrowanej ochrony roślin, w której zabiegów prewencyjnych nie powinno się stosować, a zabiegi chemiczne można stosować po przekroczeniu określonych progów szkodliwości (Piszczek i Mrówczyński 2012). Ilość zabiegów oraz ich terminy uzależnione są od pojawienia się i rozwoju choroby. Jest to związane głównie z rejonem uprawy buraków, a co za tym idzie od warunków klimatycznych. W oparciu o znajomość tych parametrów stworzono komputerowe modele prognozowania wystąpienia infekcji. We Włoszech modele takie opisują Battilani i wsp. (1996) oraz Meriggi i wsp. (2003). System funkcjonujący w Niemczech (CERCBET) był tworzony i doskonalony przez wiele lat (Verreet i wsp. 1996; Wolf i wsp. 2000; Wolf i Verreet 2002; Jörg i wsp. 2003; Racca i Jörg 2007). Aktualna prognoza występowania C. beticola w Niemczech dostępna jest na stronie internetowej prowadzonej przez Uniwersytet w Kilonii (Anonim 2014). Także w USA został opracowany system ostrzegania przed epifitozą chwościka (Jones i Windels 1991; Windels i wsp. 1998; Khan i wsp. 2007). Programy te, oprócz przebiegu pogody, uwzględniają także rejony uprawy, warunki siedliskowe itp. Najnowsze programy predykcyjne potrafią doprowadzić do oszczędności w stosowaniu fungicydów bez straty plonu, oszczędzając średnio od 0,9 do 1,6 zabiegu na sezon wegeta- cyjny (Cioni i wsp. 2013). Przyjmuje się, że pierwszy zabieg powinien być wykonany, gdy porażenie obejmie nie więcej niż 5\% powierzchni liści. Jednak najlepsze efekty ochronne otrzymuje się, gdy zabieg wykonany jest jeszcze przed pojawieniem się objawów choroby. Zabiegi spóźnione nie zapobiegają rozwojowi choroby i są mniej skuteczne (Wolf i Verreet 2002). Obserwacje te potwierdza Piszczek (2010). Prowadzone były także badania nad zastosowaniem flutriafolu jako zaprawy nasiennej (Kimmel i Potyondi 1999) chroniącej buraka przed C. beticola, w których osiągnięto pozytywne wyniki. W praktyce, kombinacja uprawy odmian odpornych i zabiegów chemicznych jest podstawą skutecznego zwalczania chwościka buraka (Ioannidis i Karaoglanidis 2010). Do wczesnego wykrywania grzyba w liściach można używać testów markerowych (Balau i Faretra 2010). Dostępne są także informacje o wczesnej detekcji grzyba w glebie za pomocą testu ELISA (Ali 2012).

Podejmowane były także próby biologicznej ochrony buraka przed $C$. beticola z wykorzystaniem Bacillus mycoides oraz kwasu salicylowego (Bargabus i wsp. 2003; Bargabus-Larson i Jacobsen 2007). Bakterie z rodzaju $B a-$ cillus były wykorzystywane także przez Esh i wsp. (2011). Ochronne działanie preparatów biologicznych Sincocin i Agrispon opartych na wyciągach roślinnych opisał Gado (2007). Galletti i wsp. (2008) przedstawiali podobne prace z wykorzystaniem grzybów z rodzaju Trichoderma. Prace prowadzone w Polsce wskazały, że preparaty Biosept $33 \mathrm{SL}$ i Biochicol 020 PC oparte odpowiednio na ekstrakcie z grejpfruta i chitozanie ograniczały występowanie C. beticola na buraku ćwikłowym (Sadowski i wsp. 2007). Podobne wnioski wysunęła Szymczak-Nowak (2009) w badaniach prowadzonych na buraku cukrowym.

Wpływ nawożenia na występowanie chwościka buraka jest niejednoznaczny (Górski 2009). Li i wsp. (2011) stwierdzili, że prawidłowe i zrównoważone nawożenie poprawia zdrowotność roślin, ale wskazują oni na obniżenie odporności roślin występujące w wyniku niskiego nawożenia azotem.

\section{Odporność na fungicydy / Fungicide resistance}

Odporność grzybów patogenicznych na fungicydy jest zjawiskiem powszechnym (Brent i Hollomon 2007; Anonim 2013). Poziom zróżnicowania genetycznego $C$. beticola jest wysoki (Weiland i Halloin 2001; Moretti i wsp. 2004, 2006) i jest to także obserwowane na poziomie fenotypowym (Ruppel 1972; Whitney i Lewellen 1976; Moretti i wsp. 2006, 2010). Grzyb należy do patogenów, które szybko nabywają odporność na substancje czynne fungicydów (Bolton i wsp. 2013). Jest to spowodowane między innymi produkcją dużej liczby zarodników konidialnych, wielokrotnym powtarzaniem infekcji $\mathrm{w}$ trakcie sezonu wegetacyjnego, czy wspomnianą już znaczną zmiennością genetyczną grzyba 
(Ma i Michailides 2005; Deising i wsp. 2008). Ochronne zabiegi chemiczne działają na $C$. beticola jak swoiste sito selekcyjne, powodując wzrost liczby odpornych izolatów grzyba (Karaoglanidis i wsp. 2002). Stosowanie fungicydów o takim samym sposobie działania dodatkowo sprzyja powstawaniu odpornych populacji grzyba (Delp i Dekker 1985). Secor i wsp. (2010) donoszą o izolatach C. beticola odpornych na organiczne związki cyny, tiofanat metylowy, triazole i strobiluryny. Wiele doniesień o odporności C. beticola na fungicydy pochodzi z Grecji (Karaoglanidis i wsp. 2000, 2003; Karaoglanidis i Thanassoulopoulos 2003; Karaoglanidis i Bardas 2006). Także na terenie Turcji odkryto izolaty odporne na fungicydy (Colak Tumbek i wsp. 2011). Pierwsze doniesienia o odporności C. beticola na fungicydy w Polsce datują się na 2003 i 2004 rok (Piszczek 2003, 2004). Piszczek (2010) stwierdził, że około $50 \%$ populacji $C$. beticola $\mathrm{z}$ centralnej Polski jest odporne na fungicydy benzimidazolowe. Po zaprzestaniu stosowania fungicydów, na które $C$. beticola nabył odporności, ich frekwencja w populacji grzyba nie zmniejsza się. Powtórne zastosowanie nieskutecznych fungicydów powoduje przyrost częstotliwości występowania odpowiednich genotypów (Karaoglanidis i wsp. 2003), a ich eliminacja jest bardzo trudna (Campbell i wsp. 1998). Odporność na fungicydy nie zanika po długotrwałym przechowywaniu izolatów na pożywce. Wskazuje to na trwałość tej cechy (Piszczek 2010).

Cercospora beticola jest jednym z pierwszych gatunków, który uodpornił się na fungicydy z grupy benzimidazoli. Pierwsza odporność na benomyl została zaobserwowana w Grecji po trzech latach od wprowadzenia tej substancji czynnej do ochrony buraka cukrowego (Georgopulos i Dovas 1973). Następne badania potwierdziły uodpornienie się grzyba na tiofanat metylowy w USA (Campbell i wsp. 1998). Kolejne odporności w USA zaobserwowali Bugbee (1995), Campbel i wsp. (1998), Briere i wsp. (2001) oraz Kirk i wsp. (2012). Fungicydy benzimidazolowe łączą się z tubuliną grzybową, czego konsekwencją jest zahamowanie mitozy oraz zakłócenie funkcjonowania cytoszkieletu (Davidse 1986; Ma i Michailides 2005). Przyczyną nabywania odporności patogenów na bezimidazole jest głównie powstawanie mutacji pojedynczego nukleotydu, powodujących zmiany w sekwencji aminokwasów białka $\beta$-tubuliny, a w efekcie zmniejszenie powinowactwa wiązania substancji grzybobójczej (Sisler 1988). Badania molekularne sekwencji genu ß-tubuliny szczepów odpornych różnych grzybów wykazały istnienie kilku mutacji, odpowiedzialnych za powstawanie odporności na fungicydy benzimidazolowe. Najpowszechniejszą z nich jest zamiana w 198 pozycji kodonu, identyfikowana między innymi u Tapesia yallundae i Tapesia acuformis (Albertini i wsp. 1999), Monilinia fructicola (Ma i wsp. 2003) oraz u C. beticola (Davidson i wsp. 2006; Suwan i wsp. 2012; Trkulja i wsp. 2013). W opisywanej pozycji kodonu dochodzi do zamiany kwasu glutaminowego alaniną, glicyną, lizyną lub waliną (Albertini i wsp. 1999). Zmiana kwasu glutaminowego alaniną (E198A) jest jedyną dotychczas opisaną mutacją odpowiedzialną za wysoki poziom odporności na benzimidazole u sprawcy chwościka buraka (Davidson i wsp. 2006; Trkulja i wsp. 2013). W sekwencji genu ß-tubuliny u C. beticola Trkulja i wsp. (2013) zidentyfikowali także mutację F167Y, czyli zamianę fenyloalaniny tyrozyną w 167 pozycji kodonu. Określili jednak, że ta mutacja występowała tylko u izolatów mało lub umiarkowanie odpornych na związki benzimidazolowe.

Triazole stanowią ważną grupę fungicydów systemicznych, wykorzystywanych w ochronie roślin od lat 70 . poprzedniego wieku. Związki te hamują działanie $14 \alpha$-dimetylazy sterolu, enzymu uczestniczącego w syntezie ergosterolu (Karaoglanidis i Ioannidis 2010). Zablokowanie prawidłowego funkcjonowania enzymu prowadzi do magazynowania intermediatów ergosterolu, co powoduje zmiany w funkcjonowaniu i strukturze błony komórkowej (Lepesheva i Waterman 2007). W warunkach laboratoryjnych odporność na substancje czynne z grupy triazoli jako pierwsi zaobserwowali Henry i Trivellas (1989). Najczęstszym powodem spadku wrażliwości grzybów na związki triazolowe są mutacje powstające w genie $14 \alpha$-dimetylazy sterolu (cyp51). Dotychczas zdiagnozowano kilkanaście mutacji odpowiedzialnych za to zjawisko u różnych patogenów. Są to m.in. zamiana izoleucyny treoniną w 330 pozycji kodonu (I330T), zamiana kwasu glutaminowego lizyną w 297 pozycji kodonu (E297K) czy mutacja P384S powodująca zamianę proliny seryną w 384 pozycji kodonu (Wynard i Brown 2005; Cools i wsp. 2011). Żadna z nich nie została jak dotąd opisana u polskich izolatów $C$. beticola, więc konieczne są dalsze prace badające podstawy występowania odporności u tego gatunku. Pozostałymi przyczynami uodparniania się patogenów na tę grupę środków ochrony roślin są wzrost ekspresji genu cyp51 oraz białek transportowych, odpowiedzialnych za usuwanie fungicydów z wnętrza komórek (Nikou i wsp. 2009; Cools i wsp. 2011; Bolton i wsp. 2012).

Strobiluryny hamują procesy oddechowe zachodzące w mitochondriach poprzez łączenie się z kompleksem cytochromowym bc1. W konsekwencji dochodzi do zablokowania transferu elektronów pomiędzy cytochromem b i c1, co z kolei powoduje ograniczenie syntezy ATP (adenozynotrójfosforan) i deficyty energetyczne u grzybów (Fernandez-Ortuno i wsp. 2008; Fisher i Meunier 2008). Uodpornienie się patogena na strobiluryny może być efektem między innymi działania transportowych białek błonowych, które zapobiegają gromadzeniu się substancji toksycznych wewnątrz komórek grzybowych, czy zwiększenia aktywności alternatywnej oksydazy, dzięki czemu blokowany cytochrom b zostaje ominięty (Fernandez-Ortuno i wsp. 2008). Jednak najważniejszą przyczyną nabywania odporności przez C. beticola na opisywaną grupę związków 
chemicznych są mutacje punktowe, zmieniające sekwencję aminokwasów białka cytochromu b, a tym samym osłabiające lub całkowicie uniemożliwiające przyłączenie fungicydu (Fernandez-Ortuno i wsp. 2008). U większości grzybów odpornych na strobiluryny identyfikowana jest mutacja G143A, czyli zamiana glicyny alaniną w 143 pozycji kodonu. Jeszcze do 2013 roku mutacja G143A nie została odnotowana w Polsce, choć obserwowano wzrost odporności na strobiluryny (Pieczul i Perek 2015). Zaledwie dwa lata później Piszczek i wsp. (2018) zidentyfikowali tę mutację u izolatów $C$. beticola pochodzących ze wschodniej Polski, a Kiniec i wsp. (2017) zauważyli szybkie, niekorzystne zmiany w populacji patogena i gwałtowny wzrost obecności mutacji G143A. Inne opisywane mutacje to między innymi zamiana fenyloalaniny leucyną w 129 pozycji kodonu (F129L) czy zamiana glicyny argininą w pozycji 137 (G137R) (Fernandez-Ortuno i wsp. 2008; Fisher i Meunier 2008; Bolton i wsp. 2013).

Najskuteczniejszym działaniem ograniczającym zagrożenie pojawiania się w populacji $C$. beticola nowych odporności jest stosowanie w programie ochrony do kolejnych zabiegów fungicydów o innych mechanizmach działania oraz ich mieszanek (Khan 2018). Jak wskazują ostatnio prowadzone badania, bardzo dobre efekty ochronne, równocześnie zapewniające ograniczenie ryzyka powstawania odporności, daje wprowadzenie do ochrony fungicydów działających wielopunktowo, na metabolizm grzyba, na przykład związków miedzi (Kempl 2018; Khan 2018).

\section{Literatura / References}

Albertini C., Gredt M., Leroux P. 1999. Mutations of the $\beta$-tubulin gene associated with different phenotypes of benzimidazole resistance in the cereal eyespot fungi Tapesia yallundae and Tapesia acuformis. Pesticide Biochemistry Physiology 64 (1): 17-31. DOI: 10.1006/ pest.1999.2406.

Ali A.A.-M.M. 2012. Rapid detection and quantification of Cercospora beticola in soil using PCR and ELISA assays. Dissertation zur Erlangung des Doktorgrades der Agrar-und Ernährungswissenschaftlichen Fakultät, der Christian-Albrechts-Universität zu Kiel, 144 ss.

Anonim. 2013. List of plant pathogenic organism resistant to disease control agents. Fungicide Resistance Action Committee: 13-35.

Anonim. 2014. Cercospora - Negativprognose. http://www.ips-zuckerruebe.de/.

Anonim. 2018. http://archiwum.minrol.gov.pl/Informacje-branzowe/Wyszukiwarka-srodkow-ochrony-roslin.

Balau A.-M., Faretra F. 2010. Molecular method for detection of Cercospora beticola Sacc. Lucrări Ştiinţifice 53 (1) (seria Agronomie): $181-183$.

Bargabus R.L., Zidack N.K., Sherwood J.E., Jacobsen B.J. 2003. Oxidative burst elicited by Bacillus mycoides isolate Bac j, a biological control agent, occurs independently of hypersensitive cell death in sugar beet. Molecular Plant Microbe Interactions 16 (12): $1145-1153$. DOI: 10.1094/MPMI.2003.16.12.1145.

Bargabus-Larson R.L., Jacobsen B.J. 2007. Biocontrol elicited systemic resistance in sugarbeet is salicylic acid independent and NPR1 dependent. Journal of Sugar Beet Research 44 (1-2): 17-33.

Battilani P., Giosue S., Racca P., Rossi V. 1996. A decision support system for Cercospora leaf spot management in sugar beet. s. 33-44. Proceedings of the 59th International Institute for Beet Research Congress, Brussels, 15-16 February 1996, 605 ss.

Bolton M.D., Birla K., Rivera-Varas V., Rudolph K.D., Secor G.A. 2012. Characterization of CbCyp51 from field isolates of Cercospora beticola. Phytopathology 102 (3): 298-305. DOI: 10.1094/PHYTO-07-11-0212.

Bolton M.D., Riviera V., Secor G. 2013. Identification of the G143A mutation associated with QoI resistance in Cercospora beticola field isolates from Michigan. Pest Management Science 69 (1): 35-39. DOI: 10.1002/ps.3358.

Borecki Z. 1984. Fungicydy stosowane w ochronie roślin. PWN, Warszawa, 173 ss.

Brent K.J., Hollomon D.W. 2007. Fungicide resistance in crop pathogens: How can it be managed? Fungicide Resistance Action Committee Monograph No. 1: 4

Briere S.C., Franc G.D., Kerr E.D. 2001. Fungicide sensitivity characteristics of Cercospora beticola isolates recovered for the high plains. Journal of Sugar Beet Research 38: 111-120.

Brillova D., Michalikowa A., Sladka O. 1973. Defensive reactions of the sugarbeet after the infection with Cercospora beticola Sacc. Biologia (Prace) 19: 1-65.

Brillova D., Sladka O. 1976. Some physiological changes in sugar beet after infection by Cercospora beticola Sacc. Acta Instituti Botanici Academiae Scientiarum Slovacae 1: 39-49.

Bugbee W.M. 1995. Cercospora beticola tolerant to triphenyltin hydroxide. Journal of Sugar Beet Research 32 (4): 167-174.

Burenin V.I., Pilipenko O.G. 1987. Anatomical features of the leaf apparatus of sugarbeet in relation to susceptibility to Cercospora. Sbornik Nauchnykh Trudov po Prikladnoi Botanike, Genetike i Selektsii 113: 96-101.

Campbell L.G., Smith G.A., Lamey H.A., Cattanach A.W. 1998. Cercospora beticola tolerant to triphenylt hydroxide and resistant to thiophanate methyl in North Dakota and Minnesota. Journal of Sugar Beet Research 35 (1-2): 29-41.

Cioni F., Collina M., Maines G., Khan M.F.R., Secor G.A., Rivera V.V. 2013. A new integrated pest management (IPM) model for Cercospora leaf spot of sugar beets in the Po Valley, Italy. Sugar Tech 16 (1): 92-99. DOI: 10.1007/s12355-013-0260-7.

Colak Tumbek A., Ozeren P., Kaya R., Katircioglu Y.Z., Maden S. 2011. Sensitivity of Cercospora beticola populations in Turkey to flutriafol, mancozeb, and fentin acetate. Turkish Journal of Agriculture and Forestry 35: 65-71. DOI: 10.3906/tar-0910-24.

Cools H.J., Mullins J.G.L., Fraaije B.A., Parker J.E., Kelly D.E., Lucas J.A., Kelly S.L. 2011. Impact of recently emerged sterol 14 $\alpha$-demethylase (CYP51) variants of Mycosphaerella graminicola on azole fungicide sensitivity. Applied and Environmental Microbiology 77 (11): 3830-3837. DOI: 10.1128/AEM.00027-11.

Davidse L.C. 1986. Benzimidazole fungicides: mechanism of action and biological impact. Annual Review of Phytopathology 24: 43-65. DOI: 10.1146/annurev.py.24.090186.000355. 
Davidson R.M., Hanson L.E., Franc G.D., Panella L. 2006. Analysis of $\beta$-tubulin gene fragments from benzimidazole-sensitive and tolerant Cercospora beticola. Journal of Phytopathology 154 (6): 321-328. DOI: 10.1111/j.1439-0434.2006.01080.x.

Deising H.B., Reiman S., Pascholati S.F. 2008. Mechanism and significance of fungicide resistance. Brazilian Journal of Microbiology 39 (2): 286-295. DOI: 10.1590/S1517-838220080002000017.

Delp C.J., Dekker J. 1985. Fungicide resistance: definitions and use of terms. European and Mediterranean Plant Protection Organization Bulletin 15 (3): 333-335. DOI: 10.1111/j.1365-2338.1985.tb00237.x.

Draycott A.P. (red.). 2006. Sugar Beet (World Agriculture Series). Blackwell Pub, Oxford, UK, 474 ss.

Esh A.M.H., El-Kholi M.A., Taghian S. 2011. Antagonistic activities of Bacillus amyloliquefaciens from phyllosphere of sugar beet against Cercospora beticola Sacc. Journal of Plant Protection and Pathology 2 (1): 99-116.

Feindt F., Mendgen K., Heitefuss R. 1981. Feinstruktur unterschiedlicher Zellwandreaktionen im Blattparenchym anfälliger und resistenter Rüben (Beta vulgaris L.) nach Infektion durch Cercospora beticola Sacc. Phytopathologische Zeitschrift 101: 248-264.

Fernandez-Ortuno D., Tores J.A., de Vicente A., Perez-Garcia A. 2008. Mechanism of resistance to QoI fungicides in phytopathogenic fungi. International Microbiology 11 (1): 1-9. DOI: 10.2436/20.1501.01.38.

Fisher N., Meunier B. 2008. Molecular basis of resistance to cytochrome bc1 inhibitor. Federation of European Microbiological Societies Yeast Research 8 (2): 183-192. DOI: 10.1111/j.1567-1364.2007.00328.x.

Gado E.A.M. 2007. Management of Cercospora leaf spot disease of sugar beet plants by some fungicides and plant extracts. Egyptian Journal of Phytopathology 35 (2): 1-10.

Galletti S., Burzi P.L., Cerato C., Marinello S., Sala E. 2008. Trichoderma as a potential biocontrol agent for Cercospora leaf spot of sugar beet. BioControl 53 (6): 917-930. DOI: 10.1007/s10526-007-9113-1.

Gaurilcikiene I., Deveikyte I., Petraitiene E. 2006. Epidemic progress of Cercospora beticola Sacc. in Beta vulgaris L. under different conditions and cultivar resistance. Biologija 4: 54-59.

Georgopulos S.G., Dovas C. 1973. Occurrence of Cercospora beticola strains resistant to benzimidazole fungicides in Northern Greece. Plant Disease Reporter 62: 321-324.

Górski D. 2009. Wpływ zawartości makro- i mikroelementów w liściach buraków cukrowych oraz warunków pogodowych na porażenie roślin przez chwościka buraka (Cercospora beticola Sacc.). [Effect of macro- and micronutrients content in sugar beet leaves and weather conditions on infection by Cercospora beticola Sacc.]. Progress in Plant Protection/Postępy w Ochronie Roślin 49 (3): 1264-1267.

Górski D., Piszczek J. 2008. Wpływ skracania płodozmianu na zdrowotność roślin oraz plon i jakość korzeni buraków cukrowych. [Influence of different crop rotation on plants health, beet cyst nematode Heterodera schachtii Schmidt population and sugar beet yield and quality]. Progress in Plant Protection/Postępy w Ochronie Roślin 48 (4): 1417-1420.

Henry M.J., Trivellas A.E. 1989. Laboratory-induced fungicide resistance to benzimidazole and azole fungicides in Cercospora beticola. Pesticide Biochemistry and Physiology 35 (1): 89-96. DOI: 10.1016/0048-3575(89)90106-5.

Ioannidis P.M., Karaoglanidis G.S. 2010. Control of Cercospora leaf spot and powdery mildew of sugar beet with fungicides and tolerant cultivar. s. 129-140. W: Cercospora Leaf Spot of Sugar Beet and Related Species (R.T. Lartey, J.J. Weiland, L. Panella, P.W. Crous, C.E. Windels, red.). The American Phytopathological Society Press, St. Paul, MN, 296 ss.

Jones R.K., Windels C.F. 1991. A management model for Cercospora leaf spot of sugarbeets. Minnesota Extension Service AG-FO5643-E.

Jörg E., Racca P., Mittler S., Petersen J. 2003. Forecasting models for the prediction of Cercospora leaf spot disease (Cercospora beticola) of sugar beet. Zbornik predavanj in referatov 6. Slovenskega posvetovanja o varstvu rastlin, Zreče 4-6: 199-204.

Karaoglanidis G.S., Bardas G. 2006. Control of benzimidazole- and DMI-resistant strains of Cercospora beticola with strobilurin fungicides. Plant Disease 90 (4): 419-424. DOI: 10.1094/PD-90-0419.

Karaoglanidis G.S., Ioannidis P.M. 2010. Fungicide resistance of Cercospora beticola in Europe. s. 189-211. W: Cercospora Leaf Spot of Sugar Beet and Related Species (R.T. Lartey, J.J. Weiland, L. Panella, P.W. Crous, C.E. Windels, red.). The American Phytopathological Society Press, St. Paul, MN, 296 ss.

Karaoglanidis G.S., Ioannidis P.M., Thanassoulopoulos C.C. 2000. Reduced sensitivity of Cercospora beticola isolates to steroldemethylation-inhibiting fungicides. Plant Pathology 49 (5): 567-572. DOI: 10.1046/j.1365-3059.2000.00488.x.

Karaoglanidis G.S., Ioannidis P.M., Thanassoulopoulos C.C. 2002. Changes in sensitivity of Cercospora beticola populations to sterol-demethylation-inhibiting fungicides during a 4-year period in northern Greece. Plant Patholathology 51 (1): 55-62. DOI: 10.1046/ j.0032-0862.2001.x-i2.

Karaoglanidis G.S., Karadimos D.A., Ioannidis P.M. 2003. Detection of resistance to sterol demethylation-inhibiting (DMI) fungicides in Cercospora beticola and efficacy of control of resistant and sensitive strains with flutriafol. Phytoparasitica 31 (4): 373-380.

Karaoglanidis G.S., Thanassoulopoulos C.C. 2003. Cross-resistance patterns among sterol biosynthesis inhibiting fungicides (SBIs) in. European Journal of Plant Pathology 109 (9): 929-934. DOI: 10.1023/B:EJPP.0000003672.36076.8a.

Kempl F. 2018. Control of resistant cercospora leaf spot. https://www.iirb.org/fileadmin/IIRB/Congresses/76th_IIRB_Congress/ Posters 76th IIRB Congress/3.9 Kempl_Poster 76th IIRB Congress 2018.pdf [dostęp: 2.11.2018].

Khan M.F.R. 2018. Success and limitations of using fungicides to control cercospora leaf spot on sugar beet. Agricultural Research \& Technology: Open Access Journal 14 (2): 555909. DOI: 10.19080/ARTOAJ.2018.14.555909.

Khan J., del Río L.E., Nelson R., Khan M.F.R. 2007. Improving the Cercospora leaf spot management model for sugar beet in Minnesota and North Dakota. Plant Disease 91 (9): 1105-1108. DOI: 10.1094/PDIS-91-9-1105.

Kimmel J., Potyondi L. 1999. Seed-bed treatment against Cercospora beticola in Hungary. Proceedings of 62th International Institute for Beet Research Congress, Sevilla, June 1999: 301-309.

Kiniec A., Pieczul K., Świerczyńska I., Piszczek J. 2017. Wykorzystanie analizy RFLP w monitoringu odporności Cercospora beticola na strobiluryny występującej w buraku cukrowym (Beta vulgaris L.). [The use of RFLP analysis in the monitoring of Cercospora beticola strobilurin resistance occurring in sugar beet (Beta vulgaris L.)]. Progress in Plant Protection/Postępy w Ochronie Roślin 57 (4): 300-304. DOI: 10.14199/ppp-2017-046.

Kirk W.W., Hanson L.E., Franc G.D., Stump W.L., Gachango E., Clark G., Stewart J. 2012. First report of strobilurin resistance in Cercospora beticola in sugar beet (Beta vulgaris) in Michigan and Nebraska, USA. New Disease Reports 26: 3. DOI: 10.5197/j.20440588.2012.026.003.

Koch G., Jung C. 2000. Genetic localization of Cercospora resistance genes. Cercospora beticola Sacc. s. 197-210. W: Cercospora beticola Sacc. Biology, Agronomic Influence and Control Measures in Sugar Beet (M.J.C. Asher, B. Holtschulte, M.R. Molard, 
F. Rosso, G. Steinrücken, R. Beckers, red.). Advances in Sugar Beet Reserches, International Institute for Beet Research 2 , Brussels, 215 ss.

Kole Ch. (red.). 2011. Wild Crop Relatives: Genomic and Breeding Resources Industrial Crops. Springer-Verlag Berlin Heidelberg, 183 ss. DOI: $10.1007 / 978-3-642-21102-7$.

Kovacs A. 1955. Uber die Ursachen der unterschiedlichen Resistenz der Zuckerrubensorten gegen Cercospora beticola Sacc. Phytopathologische Zeitschrift 24: 283-298.

Lepesheva G.I., Waterman M.R. 2007. Sterol 14-demethylase cytochrome P450 (Cyp51), a P450 in all biological kingdoms. Biochemica et Biophysica Acta 1770 (3): 467-477. DOI: 10.1016/j.bbagen.2006.07.018.

Li Y.-G., Li Z., Feng-Ming M. 2011. Response of Cercospora beticola in sugar beet at different cultivars and fertilization level. African Journal of Microbiology Research 5 (32): 5985-5989. DOI: 10.5897/AJMR11.1331.

Luterbacher M.C., Asher M.J.C., DeAmbrogio E., Biancardi E., Stevenato P., Frese L. 2004. Sources of resistance to diseases of sugar beet in related Beta germplasm: I. Foliar diseases. Euphytica 139 (2): 105-121. DOI: 10.1007/s10681-004-2488-5.

Ma Z., Michailides T.J. 2005. Advances in understanding molecular mechanism of fungicide resistance and molecular detection of resistant genotypes in phytopathogenic fungi. Crop Protection 24 (10): 853-863. DOI: 10.1016/j.cropro.2005.01.011.

Ma Z., Yoshimura M., Michailides T.J. 2003. Identification and characterization of benzimidazole resistance in Monilinia fructicola from stone fruit orchards in California. Applied and Environmental Microbiology 69 (12): 7145-7152. DOI: 10.1128/AEM.69.12.71457152.2003 .

Meriggi P., Rossi V., Paganini U. 2003. Cercospora leaf spot: integrated control in northern Italy. s. 333-346. 1st joint International Institute for Beet Research - American Society of Sugar Beet Technologist Congress, San Antonio, 26th February-1st March 2003, 956 ss.

Meriggi P., Rosso F., Ioannides P.M., Ayala-Garcia J. 2000. Fungicide treatments against Cercospora leaf spot in sugar beet (Beta vulgaris L.). Cercospora beticola. s. 77-102. W: Cercospora beticola Sacc. Biology, Agronomic Influence and Control Measures in Sugar Beet (M.J.C. Asher, B. Holtschulte, M.R. Molard, F. Rosso, G. Steinrücken, R. Beckers, red.). Advances in Sugar Beet Reserches, International Institute for Beet Research 2, Brussels, 215 ss.

Mesbah M., Scholten O.E., de Bock T.S.M., Lange W. 1997. Chromosome localisation of genes for resistance to Heterodera schachtii, Cercospora beticola and Polymyxa betae using sets of Beta procumbens and B. patellaris derived monosomic additions in B. vulgaris. Euphytica 97 (1): 117-127. DOI: 10.1023/A:1003088922086.

Moretti M., Karaoglanidis G., Saracchi M., Fontana A., Farina G. 2006. Analysis of genotypic diversity in Cercospora beticola Sacc. field isolates. Annals of Microbiology 56 (3): 215-221. DOI: 10.1007/BF03175008.

Moretti M., Saracchi M., Farina G. 2004. Morphological, physiological and genetic diversity within a small population of Cercospora beticola Sacc. Annals of Microbiology 54 (2): 129-150.

Moretti M., Saracchi M., Farina G. 2010. Vegetative compatibility groups in Cercospora beticola. s. 55-66. W: Cercospora Leaf Spot of Sugar Beet and Related Species" (R.T. Lartey, J.J. Weiland, L. Panella, P.W. Crous, C.E. Windels, red.). The American Phytopathological Society, St. Paul, MN, 296 ss.

Nikou D., Malandrakis A., Konstantakaki M., Vontas J., Markoglou A., Ziogas B. 2009. Molecular characterization and detection of overexpressed C-14alpha-demethylase-based DMI resistance in Cercospora beticola field isolates. Pesticide Biochemistry and Physiology 95 (1): 18-27. DOI: 10.1016/j.pestbp.2009.04.014.

Panella L., Lewellen R.T. 2007. Broadening the genetic base of sugar beet: Introgression from wild relatives. Euphytica 154 (3): $383-400$. DOI: $10.1007 / \mathrm{s} 10681-006-9209-1$.

Pfleiderer U.E., Schäufele W.R. 2000. Development of testing for resistance against Cercospora beticola in sugar beet. s. 147-154. W: Cercospora beticola Sacc. Biology, Agronomic Influence and Control Measures in Sugar Beet (M.J.C. Asher, B. Holtschulte, M.R. Molard, F. Rosso, G. Steinrücken, R. Beckers, red.). Advances in Sugar Beet Reserches, International Institute for Beet Research 2, Brussels, 215 ss.

Pieczul K., Perek A. 2015. Przyczyny odporności izolatów Cercospora beticola (chwościk buraka) na strobiluryny w Wielkopolsce. [The reasons of strobilurin resistance Cercospora beticola (cercospora leaf spot) isolates in Wielkopolska region]. Progress in Plant Protection/Postępy w Ochronie Roślin 55 (1): 45-48. DOI: 10.14199/ppp-2015-008.

Piszczek J. 2003. Odporność niektórych szczepów Cercospora beticola Sacc. na Duett 250 SC stosowany w uprawie buraka cukrowego w Polsce. [Resistance of strains of Cercospora beticola Sacc. to fungicide Duett 250 SC used for sugar beet protection in Poland]. Progress in Plant Protection/Postępy w Ochronie Roślin 43 (1): 869-871.

Piszczek J. 2004. Odporność niektórych szczepów Cercospora beticola Sacc. na fungicydy stosowane w ochronie buraka cukrowego. [Resistance of selected strains of Cercospora beticola Sacc. to fungicides used for sugar beet protection in Poland]. Progress in Plant Protection/Postępy w Ochronie Roślin 44 (2): 1028-1031.

Piszczek J. 2010. Epidemiologia chwościka buraka cukrowego (Cercospora beticola) w centralnej Polsce. Rozprawy Naukowe Instytutu Ochrony Roślin - Państwowego Instytutu Badawczego, Zeszyt 23, 70 ss.

Piszczek J., Mrówczyński M. (red). 2012. Metodyka integrowanej ochrony buraka cukrowego i pastewnego dla doradców. Instytut Ochrony Roślin - Państwowy Instytut Badawczy, Poznań, 123 ss.

Piszczek J., Pieczul K., Kiniec A. 2018. First report of G143A strobilurin resistance in Cercospora beticola in sugar beet (Beta vulgaris) in Poland. Journal of Plant Diseases and Protection 125 (1): 99-101. DOI: 10.1007/s41348-017-0119-3.

Pool V.W., McKay M.B. 1916. Relation of stomatal movement to infection by Cercospora beticola. Journal of Agriculture Researches 5 (22): 1011-1038.

Racca P., Jörg E. 2007. CERCBEET 3 - a forecaster for epidemic development of Cercospora beticola. Bulletin of European and Mediterranean Plant Protection Organization 37 (2): 344-349. DOI: 10.1111/j.1365-2338.2007.01136.x.

Rossi V. 1995. Effect of host resistance in decreasing infection rate of Cercospora leaf spot epidemics on sugarbeet. Phytopathologia Mediterranea 34 (3): 149-156.

Rossi V. 2000. Cercospora leaf spot infection and resistance in sugar beet. s. 17-48. W: Cercospora beticola Sacc. Biology, Agronomic Influence and Control Measures in Sugar Beet (M.J.C. Asher, B. Holtschulte, M.R. Molard, F. Rosso, G. Steinrücken, R. Beckers, red.). Advances in Sugar Beet Reserches, International Institute for Beet Research 2, Brussels, 215 ss.

Rossi V., Battilani P. 1990. Dinamica delle epidemie di Cercospora beticola Sacc. su barbabietola da zucchero. III. Ruolo della suscettibilità varietale. Phytopathologia Mediterranea 29: 114-119. 
Rossi V., Battilani P., Chiusa G., Giosuè S., Languasco L., Racca P. 1999. Components of rate-reducing resistance to Cercospora leaf spot in sugar beet: incubation length, infection efficiency, lesion size. Journal of Plant Pathology 81 (1): 25-35.

Rossi V., Meriggi P., Biancardi E., Rosso F. 2000. Effect of Cercospora leaf spot on sugar beet growth, yield and quantity. s. 49-76. W: Cercospora beticola Sacc. Biology, Agronomic Influence and Control Measures in Sugar Beet (M.J.C. Asher, B. Holtschulte, M.R. Molard, F. Rosso, G. Steinrücken, R. Beckers, red.). Advances in Sugar Beet Reserches, International Institute for Beet Research 2, Brussels, 215 ss.

Ruppel E.G. 1972. Variation among isolates of Cercospora beticola from sugar beet. Phytophatolology 62: 134-136.

Sadowski Cz., Lenc L., Korpal W. 2007. Badania nad możliwością ochrony buraka ćwikłowego przed chorobami grzybowymi w uprawie ekologicznej. [Investigations on the possibility of protection of organically grown red beet against fungal diseases]. Journal of Research and Application in Agricultural Engineering 52 (4): 38-44.

Schäfer-Pregl R., Borchardt D.C., Barzen E., Glass C., Mechelke W., Seitzer J.F., Salamini F. 1999. Localization of QTLs for tolerance to Cercospora beticola on sugar beet linkage groups. Theoretical and Applied Genetics 99 (5): 829-836. DOI: 10.1007/ s001220051302.

Schlösser E. 1969. A review of some mechanisms of resistance of sugar beet to Cercospora beticola. Journal of International Institute for Beet Research 4: 185-191.

Secor G.A., Rivera-Varas V.V., Gudmestad N.C., Weiland J.J. 2010. Sensitivity of Cercospora beticola to foliar fungicides in the Red River Valley of North Dacota and Minesota. s. 213-222. W: Cercospora Leaf Spot of Sugar Beet and Related Species (R.T. Lartey, J.J. Weiland, L. Panella, P.W. Crous, C.E. Windels, red.). The American Phytopathological Society, St. Paul, MN, 296 ss.

Sisler H.D. 1988. Fungicidal action and fungal resistance mechanisms. s. 6-8. W: Fungicide Resistance in North America (C.J. Delp, red.). The American Phytopathological Society Press, St. Paul, MN, 133 ss.

Smith G.A., Campbell L.G. 1996. Association between resistance to and yield in commercial sugarbeet hybrids. Plant Breeding 115: $28-32$

Smith G.A., Gaskill O. 1970. Inheiritance of resistance to Cercospora leaf spot in sugarbeet. Journal of American Society of Sugar Beet Technologists 16: 172-180.

Smith G.A., Ruppel E.G. 1974. Heritability of resistance to Cercospora leaf spot in sugar beet. Crop Science 14: 113-115.

Solel Z., Minz G. 1971. Infection process of Cercospora beticola in sugar beet in relation to susceptibility. Phytopathology 61: $463-466$. DOI: 10.1094/Phyto-61-463.

Srobarova A., Brillova D. 1982. Localization of defence substances in the leaves of sugar beet infected by Cercospora beticola. Sbornik UVTIZ, Ochrana Rostlin 18: 115-123.

Steinkamp M.P., Martin S.S., Hoefert L.L., Ruppel E.G. 1979. Ultrastructure of lesions produced by Cercospora beticola in leaves of Beta vulgaris. Physiological Plant Pathology 15 (1): 13-26.

Suwan N., Nuandee N., Akimitsu K., Nalumpang S. 2012. Analysis of $\beta$-tubulin gene from carbendazim resistant isolates of Cercospora lactucae-sativae on lettuce in Thailand. Journal of Agricultural Technology 8 (2): 711-723.

Szymczak-Nowak J. 2009. Wpływ biostymulatorów na zdrowotność i plonowanie buraka cukrowego. [Effect of biostimulators on health and yielding of sugar beet]. Progress in Plant Protection/Postępy w Ochronie Roślin 49 (4): 2031-2037.

Trkulja N., Ivanović Ž., Pfaf-Dolovac E., Dolovac N., Mitrović M., Toševski I., Jović J. 2013. Characterisation of benzimidazole resistance of Cercospora beticola in Serbia using PCR-based detection of resistance associated mutations of the $\beta$-tubulin gene. European Journal of Plant Pathology 135 (4): 889-902. DOI: 10.1007/s10658-012-0135-x.

Vereijssen J., Schneider J.H.M., Termorshuizen A.A.J. 2005. Root infection of sugar beet by Cercospora beticola in a climate chamber and in the field. European Journal of Plant Pathology 112 (3): 201-210. DOI: 10.1007/s10658-004-4172-y.

Verreet J.A., Wolf P.F.J., Weis F.J. 1996. Bekämpfungsschwellen als Grundlage für eine integrierte Bekämpfung von Cercospora beticola: das IPS Modell Zuckerrübe. s. 55-69. Proceedings of the 59th International Institute for Beet Research Congress, Brussels, 15-16 February 1996, 605 ss.

Weiland J.J., Halloin J.M. 2001. Benzimidazole resistance in Cercospora beticola sampled from sugarbeet fields in Michigan, USA. Canadian Journal of Plant Pathology 23 (1): 78-82. DOI: 10.1080/07060660109506912.

Weiland J., Koch G. 2004. Sugarbeet leaf spot disease (Cercospora beticola Sacc.) dagger. Molecular Plant Pathology 5 (3): 157-166. DOI: $10.1111 /$ j.1364-3703.2004.00218.x.

Whitney E.D., Lewellen R.T. 1976. Identification and distribution of races C1 and C2 of Cercospora beticola from sugar beet. Phytopathology 66: 1158-1160. DOI: 10.1094/Phyto-66-1158.

Whitney E.D., Mann N.F. 1981. Effect of resistance on growth of Cercospora beticola race C2 on the leaf surface and within leaf tissue of sugar beet. Phytopathology 71: 633-638. DOI: 10.1094/Phyto-71-633.

Windels C.E., Lamey H.A., Hilde D., Widner J., Knudsen T. 1998. A Cercospora leaf spot model for sugar beet. In practice by an industry. Plant Disease 82 (7): 716-726.

Wolf P.F.J., Verreet J.A. 2002. An integrated pest management system in Germany for the control of fungal leaf diseases in sugar beet. The IPM sugar beet model. Plant Disease 86 (4): 336-344.

Wolf P.F.J., Verreet J.A., Maier J., Kohler R. 2000. An integrated pest managment (IPM sugar beet model) for thereshold-oriented control of Cercospora beticola on sugar beet, developed under conditions in Southern Germany. s. 103-122. W: Cercospora beticola Sacc. Biology, Agronomic Influence and Control Measures in Sugar Beet (M.J.C. Asher, B. Holtschulte, M.R. Molard, F. Rosso, G. Steinrücken, R. Beckers, red.). Advances in Sugar Beet Reserches, International Institute for Beet Research 2, Brussels, 215 ss.

Wynard R.A., Brown J.K.M. 2005. Sequence variation in the Cyp51 gene of Blumeria graminis associated with resistance to sterol demethylase inhibiting fungicides. Fungal Genetics and Biology 42 (8): 726-735. DOI: 10.1016/j.fgb.2005.04.007. 